Nowoczesne Systemy Zarządzania

Zeszyt 12 (2017), nr 3 (lipiec-wrzesień)

ISSN 1896-9380, s. 29-40

Modern Management Systems

Volume 12 (2017), No. 3 (July-September)

ISSN 1896-9380, pp. 29-40
Instytut Organizacji i Zarządzania

Wydział Cybernetyki

Wojskowa Akademia Techniczna

w Warszawie

Institute of Organization and Management

Faculty of Cybernetics

Military University of Technology

\title{
Smart city. Ujęcie nowych technologii w koncepcji inteligentnego miasta
}

\section{Smart city. The conceptualization of new technologies in the smart city idea}

\author{
Sabina Baraniewicz-Kotasińska \\ Uniwersytet Opolski
}

\begin{abstract}
AbstraKt. Celem niniejszego artykułu jest analiza roli nowych technologii informacyjno-komunikacyjnych (ICT) w koncepcji smart city oraz ocena ich udziału w tworzeniu inteligentnych miast. Smart city to nowatorska koncepcja rozwoju współczesnych miast, która nie posiada jednej, powszechnie przyjętej definicji. Spory w debatach na temat smart city dotyczą nie tylko polskiego tłumaczenia czy kwestii możliwości określania metropolii mianem inteligentnych, ale także udziału nowych technologii w kształtowaniu zrównoważonego, mądrego miasta. Rozważania podjęte w artykule mają charakter teoretyczny i omawiają m.in. różne ujęcia koncepcji smart city oraz odpowiedniego podejścia do nowych technologii. W prawidłowym rozumieniu koncepcji smart city, jak również w samych procesach zarządzania inteligentnym miastem nowe technologie odgrywają istotną rolę i mogą pomóc władzom miejskim poradzić sobie z wyzwaniami współczesności powstającymi na skutek wzrastającej liczby mieszkańców miast.
\end{abstract}

Słowa kluczowe: smart city, nowe technologie, inteligentne miasto, ICT.

Abstract: The aim of here presented article is to analyse the role of Information and Communication Technologies (ICT) in a smart city concept and to evaluate their participation in the creation of smart cities. A smart city is an innovative concept which concerns a development of the modern cities. The idea of smart cities does not have one common definition. The disputes in the debates on smart city concern not only the issue of possibility of defining the metropolis as intelligent, but also the participation of new technologies in the development of the sustainable, bright cities. The reflections are theoretical and discuss, among others, different views of the smart city concept and approaches to new technologies within them. In the proper understanding of the smart city concept, as well as in the very processes of managing a smart city, new technologies play an important role and can help the city authorities cope with the challenges of modern times generated because of the growing number of city population.

Keywords: smart city, new technologies, intelligent city, ICT. 


\section{Wstęp}

Miasta stanowią przestrzeń rozwoju cywilizacyjnego, tu tworzy się dorobek kulturowy narodowego dziedzictwa, rozwija się przemysł, społeczna komunikacja, tu na nasze codzienne życie mają bezpośredni wpływ polityczne decyzje. Prognozuje się, że do 2050 roku liczba mieszkańców miast przekroczy 6 mld, czyli 70\% ludności (United Nations, 2014, s. 20). Z tego też powodu ośrodki miejskie stają się jednymi z głównych aren przyszłego rozwoju polityczno-gospodarczego. Świadome tych, a także innych wyzwań współczesności, wiele miast decyduje się na działanie zgodne z koncepcją smart city, gdyż jej rozwiązania uwzględniają problemy ośrodków miejskich - zarówno aktualne, jak i te, które przyniesie przyszłość - i starają się im zaradzić lub zmniejszyć ich negatywne oddziaływanie na środowisko oraz społeczeństwo.

$\mathrm{W}$ koncepcji smart city można dostrzec pewien potencjał w procesie ewolucji miast; możliwości, które przyniósł ze sobą internet, wytyczyły nowy kierunek dla rozwoju i zarządzania miastem, umożliwiając tym samym budowanie tzw. miast przyszłości, do niedawna jeszcze rozpatrywanych jedynie w ujęciach futurologicznych. Technologie informacyjno-komunikacyjne (ICT) stały się w nich istotnym czynnikiem transformującym rzeczywistość miejską, choć wielu badaczy odrzuca ich udział w rozwoju inteligentnych miast, wskazując, że to przemyślany rozwój i zarządzanie przez ludzi kształtuje smart city.

Smart city jest ideą dość nową i na obecnym etapie jej opracowanych założeń budzi jeszcze wiele sporów. Zakłada, najogólniej rzecz ujmując, implementację nowych technologii do przestrzeni miejskiej oraz (a czasem jedynie, w zależności od sposobu postrzegania tej koncepcji) zrównoważony, inteligentny sposób zarządzania miastem w celu poprawy jego funkcjonowania oraz podwyższenia jakości życia jego mieszkańców.

Celem niniejszego artykułu - w obliczu panującego sporu o udział nowych technologii w kształtowaniu inteligentnych miast - jest zastanowienie się nad rolą ICT $\mathrm{w}$ koncepcji smart city i ocena ich udziału w tworzeniu inteligentnych miast. $\mathrm{Z}$ tego powodu autorka podejmuje próbę przedstawienia różnych ujęć koncepcji smart city, proponuje własną definicję tego pojęcia oraz dokonuje analizy treści strategicznych dokumentów na temat inteligentnych miast i przeglądu literatury przedmiotu. Rozważania mają charakter teoretyczny i stanowią wstęp do badań empirycznych autorki oraz dalszych refleksji na temat inteligentnych miast.

\section{Smart city - pojęcie i rozumienie}

Pojęcie smart city, a ściślej ujmując, jego polskie tłumaczenie, jak również sama koncepcja „inteligentnego miasta” budzą wiele kontrowersji. W sporze o wskazanie najadekwatniejszego polskiego odpowiednika angielskiego przymiotnika smart 
uczestniczą zarówno naukowcy, jak i samorządowcy, przedsiębiorcy oraz specjaliści z branży IT. Bazując na ustaleniach organizowanych w Polsce konferencji specjalistycznych dotyczących smart city oraz toczących się dyskusjach, autorka wyróżniła trzy szkoły definiowania tego pojęcia: jedna posługuje się popularnym terminem „inteligentne miasto"; druga, przypisując inteligencję wyłącznie istotom żywym, preferuje inne tłumaczenia słowa smart, takie jak: zdolny, mądry, bystry, sprytny; ostatnia zaś proponuje własną terminologię i tłumaczy termin smart city jako miasto przyjazne, przemyślane, mądrze zarządzane, a nawet użyteczne.

Brak powszechnie akceptowanego tłumaczenia na polski wyrażenia smart city wynikać może poniekąd $\mathrm{z}$ braku adekwatnego odpowiednika w polszczyźnie (Co znaczy, że miasto jest inteligentne, mądre, bystre? Czy miasto w ogóle może być inteligentne i mądre?), a już na pewno z problemu definicyjnego, jakiego przysparza sama koncepcja. Zarówno w literaturze polskiej, jak i zagranicznej nie występuje jedna powszechnie przyjęta definicja smart city (Stawasz, Sikora-Fernandez, Turała, 2012, s. 99), co utrudnia rozumienie samego pojęcia i wywołuje spory w debatach nad tym, które działania podjęte w ramach rozwoju miasta pozwalają na określenie go mianem smart city. Najczęściej tą sporną kwestią okazuje się być rola zaawansowanych technologii w kształtowaniu i funkcjonowaniu smart city.

Dla części badaczy wykorzystywanie technologii informacyjno-komunikacyjnych (ICT, ang. Information and Communication Technologies) do rozwoju miasta, jak i w procesie zarządzania nim jest jednym z najistotniejszych elementów kształtujących miasta inteligentne. W ten sposób definiują smart city D. Gotlib oraz R. Olszewski. Mianem smart city określają miasta, które dostępne technologie traktują niczym koło zamachowe rozwoju (Gotlib, Olszewski, 2016, s. 11). M. Muraszkiewicz, posługując się terminem „inteligentne miasto”, tłumaczy je jako „miasto, które szeroko wykorzystuje nowe, inteligentne techniki i technologie oraz innowacyjne metody organizacji życia”. To właśnie technologiom ICT przypisuje decydujący wpływ na zmiany zachodzące w rzeczywistości miejskiej, nie tylko w kwestii kształtowania infrastruktury miasta, ale także zarządzania nim (Muraszkiewicz, 2016, s. 18-19). Podobnie pojęcie inteligentnego miasta definiują D. Stawasz oraz D. Sikora-Fernandez, polskie badaczki zajmujące się problematyką smart city. Smart city ujmują w kategorii nowatorskiej myśli nastawionej na to, aby przy wykorzystaniu środków technicznych, jakie oferują najnowsze technologie, zarządzać miastem w sposób nowoczesny, a ponadto „zgodnie z zasadami ekologii, przy zachowaniu tendencji do oszczędności zasobów i uzyskiwania spodziewanych efektów" (Stawasz, Sikora-Fernandez, 2015, s. 19).

Niektórzy badacze i specjaliści IT nie wiążą jednak smart city (w powszechnym tłumaczeniu: miasto inteligentne) z inteligencją systemów teleinformatycznych. Przymiotnik „inteligentny” odnoszą bardziej do sposobu zarządzania miastem właśnie w sposób mądry i zrównoważony. Takie rozumienie nierzadko odrzuca też pogląd, jakoby obecność nowych technologii w przestrzeni miasta stanowiła jeden 
z głównych czynników warunkujących możliwość definiowania go jako smart city. $\mathrm{Z}$ tego powodu uważają, że to nie technologie ICT determinują smart city, lecz raczej np. ludzka kreatywność, szybkie i mądre rozwiązywanie problemów miasta czy racjonalne podejmowanie trudnych decyzji ze świadomością ich konsekwencji na przyszłość przez odpowiedzialne grupy zarządzające - a więc właśnie te czynniki, w których decydującą rolę pełni człowiek ze swą inteligencją, a nie technologia.

Tezę definiującą smart city jako systemy informatyczne odrzuca Marek Bielski, członek zarządu firmy Siemens, globalnego producenta i dostawcy innowacyjnych technologii w dziedzinie infrastruktury, również dla miast. Uważa on, że element technologiczny w smart city wcale nie jest najważniejszy, a smart city określa jako „miasto przyjazne mieszkańcom, mądrze zarządzane, gdzie rzeczy potrzebne znajdują się zawsze we właściwym miejscu i czasie" (Nowak, 2016). Dzięki takiemu definiowaniu smart city również mniejsze ośrodki miejskie mogą stać się „smart” i to bez potrzeby zastosowania często kosztownych skomputeryzowanych rozwiązań. „Smart” według Krzysztofa Kupczyka, dyrektora ds. infrastruktury energetycznej w FBSerwis, może być też miasto, którego samorząd, kierując się potrzebami mieszkańców, zamiast rozwiązań IT rozszerza trasy komunikacyjne i buduje drogę (Nowak, 2016). A. Fojud przytacza definicję smart city, w której eksperci opisują je jako „miasto dobrze zorganizowane i użyteczne, które oferuje poprzez organizację procesów, obsługę potrzeb mieszkańców, zagospodarowanie przestrzeni publicznej i potencjał wzrostu, najkorzystniejsze warunki do podnoszenia jakości życia mieszkańców i realizacji celów swoich interesariuszy". Z tego powodu badacz proponuje, aby smart city nazywać miastem użytecznym zamiast inteligentnym, gdyż taka terminologia lepiej oddaje cel, do którego powinno dążyć miasto przyszłości. Jako że miasto użyteczne „umiejętnie potrafi korzystać z technologii”, pojęcie to nie niesie ze sobą takiej konotacji z implementacją zaawansowanych technologii, jak termin miasto inteligentne. Według autora, literalne podejście do koncepcji smart city mogłoby w konsekwencji doprowadzić do tego, że mieszkańcy nowoczesnych miast byliby zmuszeni do rywalizacji z samodzielnie podejmującym decyzje bytem, dla którego jakość ich życia mogłaby nie być już priorytetem (Fojud, 2016).

Definiowanie smart city jedynie z punktu widzenia celowości samej koncepcji, a więc przez pryzmat inteligencji odnoszącej się do sposobu zarządzania, którego efektem ma być lepsza jakość życia mieszkańców, albo użyteczności miasta w kontekście poprawy jakości jego funkcjonowania budzi jednak pewne wątpliwości i każe się zastanowić nad tym, czy nie mamy do czynienia z nazywaniem w sposób nowatorski czegoś, co było już stosowane lub istniało w przeszłości i bynajmniej nie jest niczym nowym. Cóż jest prekursorskiego w samym zarządzaniu ukierunkowanym na polepszenie jakości życia i działania miasta? Wiele miast prowadziło już w przeszłości politykę prospołeczną i dążyło do poprawy jakości życia mieszkańców oraz ulepszenia miejskiej infrastruktury. Ich władze również musiały kierować się przemyślanym zarządzaniem. W efekcie mamy dziś do czynienia z takimi 
miejskimi potęgami jak Londyn, Nowy Jork czy Paryż. Sposób ich zarządzania jeszcze dwadzieścia lat temu nie był powszechnie określany w kategoriach smart city. Dzisiaj jednak jest. Jeśli zatem ideę smart city mamy rozpatrywać w kategoriach „nowatorskiej myśli” i „zarządzania w sposób nowoczesny”, o których wspominały w swojej definicji smart city D. Stawasz i D. Sikora-Fernandez, należałoby głębiej zastanowić się nad rzeczywiście nowymi narzędziami prowadzącymi do realizacji koncepcji smart city, a nie jedynie nad celem, który sam w sobie nie jest do końca nowy i do którego można dojść również za pomocą tradycyjnych, dostępnych także w przeszłości środków. Dla wielu takim wyróżniającym elementem będą właśnie zaawansowane technologie informacyjno-komunikacyjne.

\section{Kryteria konstytuujące smart city}

Jak podkreślają autorzy monografii Zarzadzanie w polskich miastach zgodnie $z$ koncepcja smart city, omawiane podejście do kwestii rozwijania miast jest wynikiem społecznej artykulacji w kontekście eliminacji i ograniczania niekorzystnych zjawisk, z którymi mieszkańcy miast muszą zmagać się na co dzień, jak również możliwości oferowanych właśnie przez nowe technologie (Stawasz, Sikora-Fernandez, 2015, s. 25).

Spory dotyczące znaczenia nowych technologii w definiowaniu, jak również funkcjonowaniu smart city mogą wynikać nie tyle $\mathrm{z}$ faktu, że brakuje powszechnie zaaprobowanej definicji smart city, ale również dlatego, że wciąż nie do końca sprecyzowano, jakie elementy tworzą takie miasto oraz jakie czynniki przesądzają o tym, że może ono zostać za „smart” uznane. Jest to o tyle trudne, że miasta posiadające własną, niepowtarzalną specyfikę, borykające się z różnymi wyzwaniami i problemami - korzystają z różnych, najlepszych dla siebie rozwiązań i sposobów zarządzania; różnych, a przez to trudnych do ujednolicenia. Nie sprzyja to kształtowaniu jednego wspólnego dla wszystkich miast standardu - wzoru smart city. Należy podkreślić, że taki wzór nie istnieje, a sama idea nie dąży też do standaryzacji rozwiązań dla wszystkich miast, gdyż uwzględnia właśnie, wspomniany powyżej, odrębny charakter każdego z nich. Zakłada ona podejmowanie takich działań, które wynikają z indywidualnej analizy specyfiki funkcjonowania danego ośrodka miejskiego, z uwzględnieniem potrzeb nie tyle samego miasta, ile miejskiej społeczności. Takie działania muszą być „smart” (a więc: bystre, mądre, przemyślane, inteligentne) i elastycznie reagować na zmiany społeczne, gospodarcze czy kulturowe, $\mathrm{z}$ uwzględnieniem indywidualnych potrzeb każdego miasta. Dlatego, o ile łatwo jest wskazać ogólny cel implementacji smart city, o tyle trudniej jednoznacznie określić, jakie ono powinno być, i za pomocą jakich środków powinno się takie stać, gdyż każde miasto może mieć inne problemy i potrzeby. 
Parlament Europejski w raporcie Mapping Smart Cities in the EU zaproponował, by przy określaniu „miejskiej inteligencji” kierować się analizą sześciu elementów, które uznano za tworzące koncepcję smart city (Manville et al., 2014, s. 26-27). Wśród nich znalazły się: smart economy, smart mobility, smart environment, smart people, smart living oraz smart governance (odpowiednio: smart gospodarka, smart transport i komunikacja, smart ludzie, smart jakość życia, smart zarządzanie; celowo nie tłumaczę smart na język polski, gdyż trudno wskazać odpowiedni uniwersalny przymiotnik w naszym języku, który oddałby ideę angielskiego terminu smart i nie wprowadzał niepotrzebnych sporów na tle semantycznym). Podejście to opiera się na zdefiniowanych w projekcie European Smart City, prowadzonym przez Wiedeński Uniwersytet Techniczny oraz Uniwersytet Techniczny w Delft, sześciu wskaźnikach wyróżniających smart city. Realizacja choćby jednego z sześciu elementów składowych smart city kwalifikuje dane miasto do nadania mu miana smart. Może to jednak stwarzać pewien paradoks: miasta mogą nazywać się inteligentnymi, mimo tego, że ich działania w ramach innych obszarów uwzględnionych w europejskich kryteriach wymagają jeszcze wielu reform. Paradoks ten pogłębia fakt, że opracowane charakterystyki są dość ogólne. Przykład: kierując się powyższymi wytycznymi, moglibyśmy określić mianem smart city miasto, które realizuje politykę prośrodowiskową (wpisuje się więc w działania na rzecz smart environment), ale którego nieodpowiedni system zarządzania transportem miejskim jest powodem tego, że mieszkańcy czekają 20 minut na przyjazd autobusu po podróży pociągiem. Trudno więc nazwać je „inteligentnym miastem”.

Działania koncentrujące się na ochronie środowiska i wykorzystywaniu odnawialnych źródeł energii wpisują się też w politykę ekomiasta, czy też miasta „zielonego" ( $\mathrm{z}$ ang. green city). Na podstawie kryteriów definiowania miast jako smart city takie ekomiasto może wpisywać się również w tę koncepcję i zostać nazwane „smart”. Oczywiście, polityka proekologiczna jest niezbywalnym elementem inteligentnego miasta, jednak spełnienie jedynie kryteriów smart environment zdefiniowanych w projekcie European Smart City, którymi są m.in.: niski poziom zanieczyszczania środowiska, zrównoważone zarządzanie zasobami czy atrakcyjność warunków naturalnych, nie powinno przesądzać o możliwości przypisywaniu miastu określenia miasta inteligentnego. Będziemy mieli do czynienia po prostu z miastem ekologicznym lub smart environment city. Należy więc rozumieć, że nie każde ekologiczne miasto będzie smart city w pełnym rozumieniu tej idei. Naturalnie każde smart city będzie jednocześnie „eko”. W tym znaczeniu koncepcja smart city jawi nam się jako swoista ewolucja, a więc kolejny etap w procesie rozwoju miast. Z wyżej opisanego powodu kryteria kwalifikujące dane miasto do smart city, będącego synonimem pewnej miejskiej synergii, powinny zakładać obecność w nim działań i elementów ze wszystkich sześciu komponentów, a nie tylko jednego.

Zarówno sześć wymiarów funkcjonowania smart city, jak i określające je czynniki i wskaźniki cząstkowe, zaproponowane przez naukowców z Wiednia i Delft, nie 
badają udziału ICT w funkcjonowaniu smart city. Zostały one opracowane w celu stworzenia rankingu inteligentnych miast średniej wielkości w Europie. Skupiają się bardziej na komponentach, które powinny charakteryzować inteligentne miasta w kontekście finalnego efektu, a nie na sposobie osiągnięcia danego celu (np. koniecznie dzięki zastosowaniu nowych technologii). Liczą się więc: innowacyjna przedsiębiorczość, produktywność i elastyczność rynku pracy, wysoki poziom kwalifikacji i edukacji mieszkańców, uczestnictwo w życiu publicznym i kulturalnym, partycypacja polityczna, lokalna i międzynarodowa dostępność sieci transportowej czy bezpieczeństwo osobiste oraz atrakcyjność turystyczna (Giffinger et al., 2007, s. 22-23).

O ile w ujęciu European Smart City technologie ICT w poszczególnych wskaźnikach sześciu grup charakteryzujących smart city nie zostały szczególnie podkreślone, o tyle z punktu widzenia opisu tych charakterystyk w raporcie Mapping Smart Cities in the EU odgrywają już one istotną rolę w kreowaniu inteligentnego miasta. Każdy z sześciu wymiarów smart city został opisany przez pryzmat ICT. Jak podkreślili autorzy tej analizy, smart city istnieje dzięki „wykorzystywaniu technologii, szczególnie ICT, do zwiększania konkurencyjności i zapewniania bardziej zrównoważonej przyszłości poprzez symbiotyczne sprzężenie sieci ludzi, biznesów, technologii, infrastruktur, konsumpcji, energii i powierzchni” (Manville et al., 2014, s. 17). To pokazuje, że w Unii Europejskiej nowe technologie uznawane są za istotny czynnik rozwoju inteligentnego miasta. Wszyscy przedstawiciele dziewięciu polskich miast, którym zadano pytanie: „Czym według Pani/Pana jest Smart City i Smart Region?" w swoich wypowiedziach również odwoływali się do technologii (Żylińska, 2016, s. 8-12). Nawet A. Fojud zaznacza, że najbardziej pomocną w dążeniu do „użyteczności” danego miasta, przez którą autor rozumie właśnie koncepcję smart city, może okazać się, paradoksalnie, nowoczesna technologia (A. Fojud, 2016). Techniki ICT, mądrze zaimplementowane i wykorzystywane w przestrzeni miejskiej, bezsprzecznie mogą więc pomóc w rozwoju miasta, a także przyczynić się do wzrostu poziomu jego „inteligencji”, zarówno tej rozumianej przez pryzmat mądrego zarządzania ośrodkiem miejskim, jak również tej uzyskiwanej na skutek obecności „inteligentnych” urządzeń w miejskiej przestrzeni.

Uwzględniając spory związane z polskim tłumaczeniem terminu smart city, inteligencją rzeczy martwych czy udziałem nowych technologii w tworzeniu inteligentnych miast, a przede wszystkim biorąc pod uwagę przemyślenia zawarte w niniejszym artykule, można spróbować stworzyć nieco bardziej precyzująca powyższe aspekty definicję smart city, choć wciąż jeszcze nie do końca idealną. W tym kontekście mianem smart city moglibyśmy określić miasto nowej generacji zarządzane w sposób zrównoważony ${ }^{1} \mathrm{w}$ oparciu o dostępne dane i przy użyciu rozważnie dobranych (z perspektywy potrzeb miasta), dostępnych technologii ICT, w celu uzyskania stałej

1 Odwołanie do koncepcji zrównoważonego rozwoju. 
poprawy jakości życia mieszkańców i usprawniania funkcjonowania miasta jako całego, zintegrowanego organizmu. Na tej podstawie moglibyśmy określać w języku polskim smart city miastem inteligentnym, pamiętając jednak, że w zaproponowanym rozumieniu inteligencja odnosić się będzie zarówno do inteligencji miasta uzyskiwanej w wyniku adoptowania zaawansowanych technologicznie rozwiązań, jak również do sposobu zarządzania i wykorzystywania informacji przez odpowiedzialne organy. Należy podkreślić, że zaprezentowana definicja nie jest ostateczna i w toku dalszych prac badawczych będzie testowana i ulepszana, choćby pod względem istotności udziału mieszkańców miast w zarządzaniu smart city.

Oczywiście sama obecność zaawansowanych technologii nie może przesądzać o tym, że miasto jest smart city. Równie ważny jest sposób zarządzania tymi technologiami, także w oparciu o pozyskiwane dane, które w smart city też odgrywają ważną rolę, co omówiono w kolejnym rozdziale. Niezmiernie istotne są więc wysokie umiejętności analityczne władz lokalnych, których inteligencja i zrównoważony sposób zarządzania miastem same w sobie także nie mogą tworzyć koncepcji smart city, gdyż na tej podstawie nie można by wykazać (biorąc pod uwagę, że koncepcja smart city jest nową ideą), że mamy do czynienia, jak już wspomniałam w poprzedniej części pracy, z czymś nowatorskim. Dostępność technologii nie może być zatem jedynym wyznacznikiem ,inteligencji” miasta, tak samo jak odpowiednie nim zarządzanie - dopiero ich połączenie może skutkować powstaniem smart city.

\section{Istota technologii informacyjno-komunikacyjnych w przestrzeni smart city}

Aby zrozumieć rolę ICT w przestrzeni smart city, należałoby również odpowiedzieć na pytanie, czym właściwie są technologie informacyjno-komunikacyjne. ICT to przede wszystkim technologie umożliwiające przetwarzanie, gromadzenie oraz przesyłanie informacji w formie elektronicznej (Berezowska et al., 2010, s. 7). $\mathrm{W}$ zakres tego pojęcia wchodzą zarówno media komunikacyjne (m.in. internet, sieci bezprzewodowe, telefonia), media umożliwiające zapis informacji (np. pamięć przenośna, dyski twarde), jak również narzędzia służące do przetwarzania informacji, takie jak np. komputer. To także aplikacje oraz złożone systemy IT umożliwiające „realizację przetwarzania i przesyłania danych na wyższym poziomie abstrakcji niż poziom sprzętowy" (Ministerstwo Transportu, Budownictwa i Gospodarki Morskiej, 2012, s. 26).

Uniwersalny charakter ICT pozwala na znalezienie im zastosowania w niemal wszystkich dziedzinach gospodarki oraz organizacji życia społecznego. W ten sposób stały się one również czynnikiem umożliwiającym transformację miejskiej rzeczywistości w smart city - kształtują chociażby nowocześniejszą infrastrukturę 
miast oraz odpowiadają za zmiany zachodzące w społeczeństwie, a także w technikach zarządzania i metodach planowania ich rozwoju (Muraszkiewicz, 2016, s. 18).

Istotną częścią sektora ICT, którą można szeroko wykorzystać w przestrzeni miejskiej, jest tzw. internet rzeczy (IoT, ang. Internet of Things). IoT to inteligentne urządzenia, najczęściej posiadające własne adresy IP, które zostały połączone w sieć $z$ innymi urządzeniami za pośrednictwem internetu. $O$,inteligencji” tych urządzeń, jak tłumaczy M. Miller, przesądza właśnie fakt podłączenia tych „,rzeczy” $z$ innymi „rzeczami” do internetu - urządzenia same w sobie nie są inteligentne, lecz podłączone do sieci, wykorzystując i analizując zbiorcze dane, mogą na ich podstawie same przewidywać i podejmować pewne akcje; system staje się więc inteligentny (oczywiście nie zyskuje zdolności stricte kognitywnych, wszystko jest kwestią odpowiedniego programowania). Poszczególne elementy takiego systemu komunikują się ze sobą w zautomatyzowany sposób niemal bez ingerencji człowieka (Miller, 2016, s. 25-27, 38). To właśnie w oparciu o dane zbierane i analizowane przez takie „inteligentne" urządzenia powinno być zarządzane inteligentne miasto - zauważa autor książki Internet rzeczy. Jak inteligentne telewizory, samochody, domy i miasta zmieniają świat (Miller, 2016, s. 16). Jak podkreślają dodatkowo D. Gotlib i R. Olszewski, bez dostępu do kompleksowej, dokładnej oraz aktualnej informacji, jak również bez narzędzi, które pozwolą na przekształcanie surowych danych w informacje i wiedzę przestrzenną, nie jest możliwe rozwiązanie problemów współczesnego miasta dążącego do miana smart city (Gotlib, Olszewski, 2016, s. 10-11).

Obecnie w wyniku rozwoju technologii służącej do pozyskiwania i analizy danych, a także świadomości na temat jej wpływu na procesy decyzyjne, rola informacji w tworzeniu innowacyjnych produktów i usług znacząco wzrosła. Informacja nierzadko warunkuje właściwy proces zarządzania miastem, a na pewno umożliwia jego efektywniejsze funkcjonowanie. To dzięki dostępowi do aktualnych danych samorządy mogą lepiej rozumieć zachodzące w środowiskach miejskich procesy, optymalizować je oraz podejmować trafne, długofalowe decyzje poparte dogłębną analizą pozyskanych informacji, a nie przeczuciami. Takie dane można też wykorzystywać do zwiększania transparentności działań władz lokalnych czy świadomości mieszkańców o stanie ich miasta, a także do stymulacji chęci udziału w działaniach na rzecz miasta (Miller, 2016, s. 306). Informacja okazuje się niezwykle ważnym elementem w procesie kreowania i funkcjonowania inteligentnych miast, dlatego też w zaproponowanej w niniejszym artykule definicji smart city jej rola została podkreślona.

W praktyce koncepcja smart city wiąże się m.in. z wdrażaniem przez władze miejskie projektów i programów związanych z możliwościami, które dają obecne technologie. Są to np.: publiczne sieci Wi-Fi, inteligentne systemy sterowania ruchem ulicznym, a także systemy lamp ulicznych dostosowujących się do natężenia światła naturalnego, aplikacje na telefon proponujące najbardziej optymalną trasę przejazdu przez miasto czy aplikacje parkingowe wskazujące nie tylko wolne 
miejsca parkingowe, ale pozwalające również uiścić opłatę za postój. Mogą to być rozwiązania tak proste, jak kioski informacyjne z ekranami dotykowymi powiadamiające $\mathrm{w}$ czasie rzeczywistym o wydarzeniach w mieście, podgrzewane ławki na przystankach autobusów, czy też, dla odmiany, tak zaawansowane, jak kompletna infrastruktura dla samochodów i autobusów elektrycznych albo dla systemów inteligentnego zarządzania produkcją i dystrybucją energii elektrycznej (tzw. smart grid). Są to przede wszystkim wszelkie inwestycje, które, jak podkreśla A. Prokopowicz, powinny przynosić założone efekty, zarówno ekonomiczne, jak i społeczne, a także przyczyniać się do podnoszenia efektywności ich działania (Prokopowicz, 2016, s. 33). Mowa zatem o działaniach potencjalnie korzystnych społecznie, mających zapewnić lepszą przepustowość ruchu ulicznego w mieście, sprawniejsze wykorzystanie zasobów publicznych, jak również lepsze zarządzanie miejskimi mediami, utylizacją odpadów, a także obszarami i budynkami publicznymi. Technologie mogą więc pomóc w ograniczaniu zatorów na lokalnych drogach, alarmowaniu służb ratowniczych o wypadkach, a nawet w sygnalizowaniu potrzeb napraw drogowych i dodatkowych patroli policji (Miller, 2016, s. 305).

Przykłady możliwości zastosowania ICT w przestrzeni miejskiej w celu usprawnienia procesów zarządzania współczesnymi miastami można mnożyć - pokazuje to, że funkcjonowanie smart city nierozerwalnie wiąże się, w mniejszym lub większym stopniu, z implementacją nowych technologii. Należy jednak pamiętać, że w tworzeniu inteligentnych miast nie chodzi o wdrażanie jak największej ilości „gadżeciarskich” usług; koncepcja smart city zakłada rozwagę $\mathrm{w}$ doborze technologii do przestrzeni miejskiej - przede wszystkim mają one wspierać główne cele inteligentnych miast: przyczyniać się do podnoszenia jakości usług dostarczanych mieszkańcom, polepszać jakość ich życia, a przy okazji obniżać koszty operacyjne miasta.

\section{Podsumowanie}

Koncepcja inteligentnego miasta pozwala na wieloaspektowe podejście do rozwoju ośrodków miejskich. Zakłada zarówno inteligentny, zrównoważony sposób zarządzania nimi, jak również wykorzystywanie tzw. inteligentnych technologii $\mathrm{w}$ przestrzeni miejskiej. W opinii części ekspertów przywołanych w artykule brak wsparcia technologicznego przy złożoności procesów zachodzących we współczesnych miastach uniemożliwia skuteczne i efektywne zarządzanie nimi. Dla niektórych $\mathrm{z}$ nich technologie informacyjno-komunikacyjne nie odgrywają jednak tak istotnej roli w procesie zarządzania miastem, jak wysokie umiejętności analityczne czy otwartość umysłu samorządowców. Abstrahując od tego, czy nowe technologie stanowią w definicji smart city główny czy poboczny czynnik rozwoju i funkcjonowania inteligentnego miasta, niewątpliwie mogą one wspomagać proces zarządzania nim, szybciej podnosić jakość życia jego mieszkańców oraz jakość i wydajność 
oferowanych przez miasto publicznych usług, choćby takich jak transport, oświetlenie, media, parking.

Rozwój technik ICT umożliwił nowy kierunek rozwoju współczesnych miast, oferując nowatorskie rozwiązania dla wielu miejskich systemów, zarówno w dziedzinie bezpieczeństwa, energetyki, administracji, transportu, ochrony środowiska, gospodarki odpadami, jak również w zarządzaniu przestrzenią. Mogą one wspomóc władze miejskie w radzeniu sobie z wyzwaniami współczesności: wzrostem liczby mieszkańców, zanieczyszczeniem środowiska, zwiększającą się liczbą pojazdów na drogach czy zagrożeniami bezpieczeństwa, a także przyczynić się do wzrostu ekonomicznego, konkurencyjności czy atrakcyjności ośrodków miejskich zarówno z punktu widzenia mieszkańców, jak i przedsiębiorców. W prawidłowym rozumieniu koncepcji smart city, jak również w samych procesach zarządzania inteligentnym miastem, nowe technologie odgrywają więc istotną rolę. Należy jednak pamiętać, że stanowią one jedynie narzędzie, a nie cel sam w sobie.

\section{BIBLIOGRAFIA}

[1] Giffinger R., Fertner C., Kramar H., Kalasek R., Pichler-Milanović N., Meijers E., 2007, Smart cities. Ranking of European medium-sized cities, Centre of Regional Science, Vienna UT, Wien.

[2] Gотьiв D., Olszewski R., 2016, Wprowadzenie, [w:] D. Gotlib, R. Olszewski (red. nauk.), Smart city. Informacja przestrzenna $w$ zarządzaniu inteligentnym miastem, Wydawnictwo Naukowe PWN, Warszawa.

[3] Manville C., Cochrane G., Cave J., Millard J., Pederson J.K., Thaarup R.K., Liebe A., Wissner M., Massink R., Kotterink B., 2014, Mapping Smart Cities in the EU, European Parliament, Brussels.

[4] Miller M., 2016, Internet rzeczy. Jak inteligentne telewizory, samochody, domy i miasta zmieniaja świat, Wydawnictwo Naukowe PWN, Warszawa.

[5] Muraszkiewicz M., 2016, Ku nowej utopii, ku inteligentnym miastom, [w:] D. Gotlib, R. Olszewski (red. nauk.), Smart city. Informacja przestrzenna w zarządzaniu inteligentnym miastem, Wydawnictwo Naukowe PWN, Warszawa.

[6] Pвокороwicz A., 2016, Walka o madre i inteligentne miasta, [w:] „Inteligentne Miasta i Regiony”, Nr $1 / 2016$

[7] Stawasz D., Sikora-Fernandez D. (red. nauk.), 2015, Zarządzanie w polskich miastach zgodnie $z$ koncepcja smart city, Wydawnictwo Placet, Warszawa.

[8] Stawasz D., Sikora-Fernandez D., Tura£a M., 2012, Koncepcja smart city jako wyznacznik podejmowania decyzji związanych z funkcjonowaniem i rozwojem miasta, [w:] „Zeszyty Naukowe Uniwersytetu Szczecińskiego. Studia Informatica”, Nr 29.

[9] UNITED NATIONS, 2015, World Urbanization Prospects: The 2014 Revision, United Nations, New York.

[10] Żylińska I., 2016, Czym wg Pani/Pana jest Smart City i Smart Region?, [w:] „Inteligentne Miasta i Regiony", $\mathrm{Nr} 1 / 2016$. 


\section{NETOGRAFIA}

[1] Berezowska J., Kamińska M., Kwiatkowska M., Niewiadomska E., Rozkrut D., Szczepańska B., Wegner M., 2010, Społeczeństwo informacyjne w Polsce. Wyniki badań statystycznych z lat 2006-2010, „Informacje i opracowania statystyczne”, Główny Urząd Statystyczny, www.stat.gov. $\mathrm{pl} / \mathrm{cps} / \mathrm{rde} / \mathrm{xbcr} / \mathrm{gus} / \mathrm{nts}$ spolecz_inform_w_polsce_2006-2010.pdf (15.11.2016).

[2] Fojud A., 2016, Dlaczego smart city warto tłumaczyć jako użyteczne miasto?, http://smartcityforum.pl/artykul/dlaczego-smart-city-warto-tlumaczyc-jako-uzyteczne-miasto/ (12.11.2016).

[3] Ministerstwo Transportu, Budownictwa i Gospodarki Morskiej, 2012, Słownik pojęć SRT, https:// docplayer.pl/26215463-Slownik-pojec-srt-ministerstwo-transportu-budownictwa-i-gospodarkimorskiej.html (15.11.2016).

[4] NowAK M., 2016, EEC 2016: Smart Cities to miasta mądrze zarzadzane, http://www.portalsamorzadowy.pl/gospodarka-komunalna/eec-2016-smart-cities-to-miasta-madrze-zarzadzane, 80729. html (03.11.2016). 